\title{
Selection of salt tolerant embryogenic line in Jatropha curcas L., which has potentiality of biodiesel
}

\author{
Chọn lọc dòng mô phôi soma chịu mặn của cây cọc rào (Jatropha curcas L.), \\ một loài cây có tiềm năng về nhiên liệu sinh học
}

Research article

Do, Dang Giap*; Tran, Dieu Thai; Tran, Trong Tuan; Nguyen, Thi Huyen Trang; Nguyen, Thi Kim Phuc; Duong, Duc Hieu

Institute of Tropical Biology, VAST, 9/621 Hanoi avenue, Linh Trung, Thu Duc district, HCMC, Vietnam

\begin{abstract}
The embryogenic calli were grown on MS medium containing $\mathrm{NaCl}$ with concentrations from 50 to $300 \mathrm{mM}$. After 2 weeks of culture, salinity tolerance threshold was identified at $150 \mathrm{mM} \mathrm{NaCl}$. Higher concentrations of $\mathrm{NaCl}$ stimulated a significant reduction in the calli survival rate and the highest rate was $78.67 \%$ at $50 \mathrm{mM}$. After subculturing callus to the embryo culture medium containing $\mathrm{NaCl}$, the growth and embryogenesis were not affected at the concentrations of $50-100$ $\mathrm{mM}$. Especially, at $50 \mathrm{mM} \mathrm{NaCl}$ the embryogenesis rate reached $83.33 \%$. In contrast, $150 \mathrm{mM} \mathrm{NaCl}$ inhibited the somatic embryogenesis. After 4 weeks, culturing somatic embryos on medium MS with addition of $0.07 \mathrm{mg} / \mathrm{l}$ spermidin at $50-100 \mathrm{mM} \mathrm{NaCl}$, the embryogenesis was considered good and embryos developed through several stages: globular, heart, torpedo and cotyledonary. However, at $150 \mathrm{mM} \mathrm{NaCl}$ the globular stage appeared in the culture process. The process of morphohistology and using dye carmine - iod and acridine orange observed the structure of generative callus and embryos at several stages.
\end{abstract}

Mô sẹo có khả năng phát sinh phôi được nuôi cấy trong môi truờng có chứa muối $\mathrm{NaCl}$ với nồng độ thay đổi tù 50 - $300 \mathrm{mM}$. Sau 2 tuần nuôi cấy, chúng tôi xác định được nguỡng chịu mặn của mô sẹo có khả năng sinh phôi cây Cọc rào là $150 \mathrm{mM}$. Nồng độ muối $\mathrm{NaCl}$ càng cao thì tỷ lệ sống của mô sẹo giảm dần và đạt giá trị cao nhất là $78,67 \%$ tại nồng độ $50 \mathrm{mM} \mathrm{NaCl}$. Khi chuyển mô sẹo sang môi truò̀ng phát sinh phôi có chứa muối $\mathrm{NaCl}$ với nồng độ thay đổi, chúng tôi thấy ở nồng độ muối NaCl 50 - 100 mM không ảnh hưởng đến khả năng sinh truớng và phát sinh phôi, đặc biệt là tại nồng độ $50 \mathrm{mM} \mathrm{NaCl} \mathrm{giúp} \mathrm{kích} \mathrm{thích} \mathrm{sự} \mathrm{hình} \mathrm{thành} \mathrm{phôi} \mathrm{tù} \mathrm{mô} \mathrm{sẹo} \mathrm{với} \mathrm{tỷ} \mathrm{lệ} \mathrm{hình} \mathrm{thành} \mathrm{phôi}$ đạt 83,33\%. Ngược lại, nồng độ tù̀ $150 \mathrm{mM} \mathrm{NaCl}$ gây ức chế quá trình hình thành phôi soma tù mô sẹo. Tiếp tuc khảo sát ảnh huơơng của muối đến khả năng phát triển và nảy mầm của phôi soma. Ghi nhận kết quả sau 4 tuần nuôi cấy phôi soma trong môi truờng $M S$ có bổ sung $0.07 \mathrm{mg} / \mathrm{l}$ spermidin, tại nồng độ $50-100 \mathrm{mM} \mathrm{NaCl} \mathrm{khả} \mathrm{năng} \mathrm{hình} \mathrm{thành} \mathrm{phôi} \mathrm{tốt} \mathrm{và} \mathrm{phôi} \mathrm{phát} \mathrm{triển} \mathrm{qua} \mathrm{các} \mathrm{giai} \mathrm{đoạn}$ phôi hình cầu, hình tim, hình thủy lôi và hình lá mầm. Đặc biệt ở nồng độ $50 \mathrm{mM}$ số luợng phôi lá mầm đạt giá trị cao với 13,33 phôi. Nồng độ muối $\mathrm{NaCl} 150 \mathrm{mM}$ chỉ xuất hiện phôi hình cầu trong suốt thời gian nuôi cấy. Quá trình giải phấu hình thái phôi và sủ dụng thuốc nhuộm 2 màu carmin - iod và acridine orange đã cho thấy rõ hơn về cấu trúc mô sẹo có khả năng sinh phôi và phôi hình thái.

Keywords: embryogenic callus, somatic embryo, salt tolerant, Jatropha curcas L., morphohistology

\section{Introduction}

In recently years, high temperature, flood, drought, thunderstorm, river erosion, rising sea level, salinization ap- pears non cyclically and effect strongly on our lives, especially the historic salinization, that prove the climate change is increasingly complicated without rule. In there, salinization is one of the interesting issues. The salinization phenomenon is encroaching inland, that impacts strongly 
on soil, plant, as well as the economic life of the people. Therefore, besides soil improvement, the improvement of plant varieties resistant to salt tolerance is an imperative solution. Salinity is a factor that effects on crop yields, especially irrigation. There were about 400 million hectares of saline ground (Flowers et al., 1977). The increase of salinity in soil has been one of serious issues that threats the survivability of crops.

Micropropagation technique is a multipurpose tool to study the behavior of cells as well as the whole plant under stress conditions. The exploitation of somaclonal variation is also useful for in vitro selection of cells and tissues against several stresses (Bajaj, 1987; Tal, 1996). In spite of limitations, salt-tolerant cell lines and plants were reported in some species, such as tomato (Hassan and Wilkins, 1988), wheat (Barakat and Abdel-Latif, 1996), rice (Lutts et al., 1999), sunflower (Alvarez et al., 2003).

Jatropha can be grown in the arid soil, harsh climate, furthermore, this plant is an economic fuel and environmental friendliness, so creating a salinity tolerance Jatropha line is one of the solutions to solve the urgent problems mentioned above. Vietnam is one of the countries that interested in the research and development of Jatropha to produce biodiesel. Jatropha brings a promise of biofuels that does not compete with other crops. In addition, Jatropha is used as medicines and has many advantages in environmental and economic benefits.

In this report, we focus to sutdy the effect of $\mathrm{NaCl}$ on the development of embryogenic callus and shoot of J. curcas. Then, selection of salt tolerant embryogenic line in Jatropha curcas L.

\section{Materials and methods}

Embryogenic callus of Jatropha curcas L., which was created and multiplicated at National Key Laboratory of Plant cell technology, Institute of Tropical Biology, was used as materials.

In this study, basal MS medium was used. Depending on experiments, plant growth regulators and $\mathrm{NaCl}$ with different concentrations were supplemented.

\subsection{Effects of the concentrations of $\mathrm{NaCl}$ on the development of embryogenic callus of $J$. curcas}

Embryogenic callus was cut into pieces and cultured on basal MS supplemented with $1.0 \mathrm{mg} / 1$ kinetin, $1.5 \mathrm{mg} / 1$ 2,4$\mathrm{D}$ (Do Dang Giap et al., 2012) and $\mathrm{NaCl}$ with different concentrations $(0,50,100,150,200,250,300 \mathrm{mM})$.

Observation target: Survival rate of callus (\%) after 2 weeks of culture.

\subsection{Effects of $\mathrm{NaCl}$ on somatic embryogenesis of in vitro J. curcas}

Embryogenic callus was cut into pieces and cultured on basal MS (Murashige and Skoog, 1962) supplemented 1.0 mg/l kinetin (Do Dang Giap et al., 2012) and $\mathrm{NaCl}$ with different concentrations within salinity tolerance threshold $(50,100,150 \mathrm{mM})$.

Observation target: Somatic embryogenesis rate (\%); Number of embryos after 4 weeks of culture.

\subsection{Effects of $\mathrm{NaCl}$ on the development and shoot formation of $\boldsymbol{J}$. curcas somatic embryos}

Somatic embryos were cultured on basal MS medium supplemented with $0.07 \mathrm{mg} / 1$ spermidine (Do Dang Giap et al., 2013) and $\mathrm{NaCl}(50,100,150 \mathrm{mM})$. The materials were subcultured on suitable embryogenesis medium.

Observation target: Total number of embryos; Number of globular embryos, heart embryos, torpedo embryos, cotyledonary embryos.

\section{Statistical analysis}

The experiments were arranged in single factor, complete randomized design. The data are recorded and analyzed by MSTATC, using LSD multiple range test.

\section{Results}

\subsection{Effects of the concentrations of $\mathrm{NaCl}$ on the development of embryogenic callus of $J$. curcas}

Table 1 showed the difference between treatments with and without (control treatment) $\mathrm{NaCl}$. The survivability of embryogenic callus of $J$. curcas decreased when increasing the concentrations of $\mathrm{NaCl}$, or survival rate of embryos was inversely propotional with the concentrations of $\mathrm{NaCl}$. In control treatment, embryogenic calli grew and developed with $100 \%$ of alive embryos. At 50, 100 and $150 \mathrm{mM} \mathrm{NaCl}$ supplemented treatments, survival rate of embryos decreased to $78.67 \%, 57.00 \%, 49.00 \%$, respectively. The higher concentrations of $\mathrm{NaCl}(200,250$ and $300 \mathrm{mM})$, the lower the survival rate of embryos $(23.67 \%, 12.33 \%$, $4.00 \%$, respectively).

Table 1. Effects of $\mathrm{NaCl}$ at different concentrations on the survivability of embryogenic callus of $J$. curcas

\begin{tabular}{cc}
$\begin{array}{c}\text { Concentrations of } \\
\text { NaCl } \\
(\mathbf{m M})\end{array}$ & $\begin{array}{c}\text { Survival rate of em- } \\
\text { bryos } \\
\mathbf{( \% )}\end{array}$ \\
\hline 0 & $100.00^{\mathrm{a}}$ \\
50 & $78.67^{\mathrm{b}}$ \\
100 & $57.00^{\mathrm{c}}$ \\
150 & $49.00^{\mathrm{d}}$ \\
200 & $23.67^{\mathrm{e}}$ \\
250 & $12.33^{\mathrm{f}}$ \\
300 & $4.00^{\mathrm{g}}$
\end{tabular}

The different letters $(a, b, c, \ldots)$ in the same column show significant differences at $\alpha$ $=0.01$ in the LSD multiple range test . 
Observing treatments supplemented $\mathrm{NaCl}$ with higher concentrations (over $150 \mathrm{mM}$ ), the survivability of embryogenic callus strongly decreased, this proved that $150 \mathrm{mM}$ of $\mathrm{NaCl}$ concentration was the salinity tolerance threshold of embryogenic callus of J. curcas (Fig $1)$.
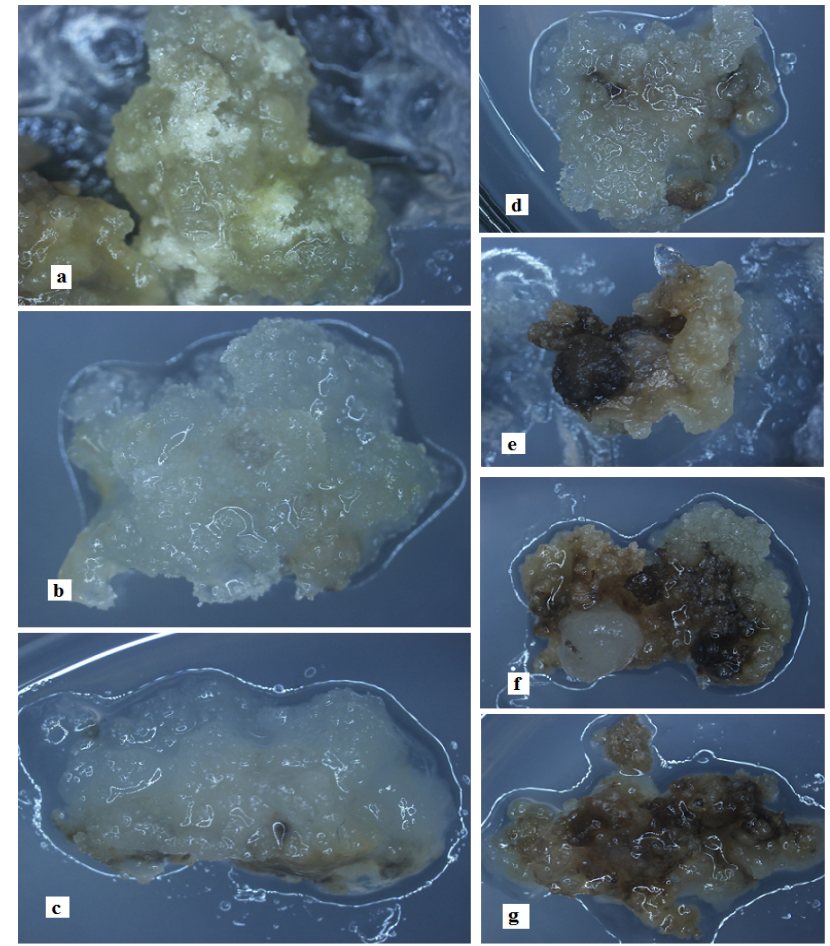

Figure 1. Embryogenic calli form on the selective medium at different concentrations of $\mathrm{NaCl}$.

a. $0 \mathrm{mM}$; b. $50 \mathrm{mM}$; c. $100 \mathrm{mM}$; d. $150 \mathrm{mM}$; e. $200 \mathrm{mM}$; f. $250 \mathrm{mM} ; \mathrm{g} .300 \mathrm{mM}$

The results of callus anatomy showed that embryogenic cells had big nucleus and concentrated cytoplasm. Nucleus and contents of cytoplasm have the affinity for carmine and stain dark pink; non embryogenic cells with big vacuole and small nuclear stain dark blue when staining by carmine-iodine. Selecting calli growing on selective media of $\mathrm{NaCl}$ at different concentrations from 50 to $150 \mathrm{mM}$ (Fig 2 ) to anatomise, red fragmented cells with integrity nucleus were collected (Fig 2d). These cell structures were similar to those on control treatment and cells color showed they were alive and growing.
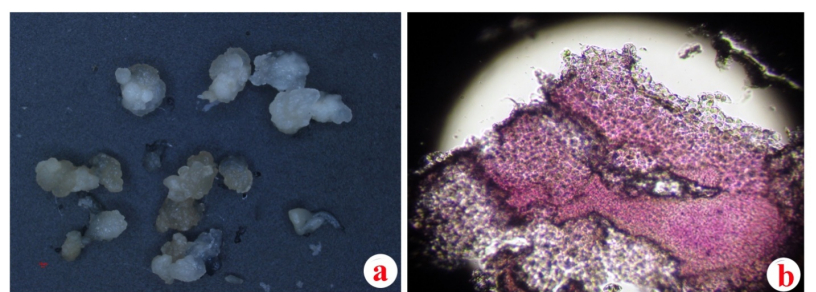

Figure 2. Morphological and anatomical structure of embryogenic callus developed on selective medium at concentrations of $50-150 \mathrm{mM} \mathbf{~ N a C l}$.

After 2 weeks of culture on saline selective medium, calli had some induction with salinity stress. To determine cell survivability, acridine orange was used. Under Fluorescence microscopy, by glowing ability of cell nucleus, redorange color defined dead cells and green defined alive cells. The anatomy results (Fig 3 ) showed that at the high concentrations of $\mathrm{NaCl}$, dead cell rate was also high; at 150 $\mathrm{mM}$ of $\mathrm{NaCl}$ (Fig 3d) there were rare dead cells, and the increase of concentrations of $\mathrm{NaCl}$ from $200 \mathrm{mM}$ to 250 $\mathrm{mM}$ (Fig 3e, f) obtained ratio of dead ascended and at treatment supplemented $300 \mathrm{mM}$ of $\mathrm{NaCl}$ (Fig 3g) most of calli died.

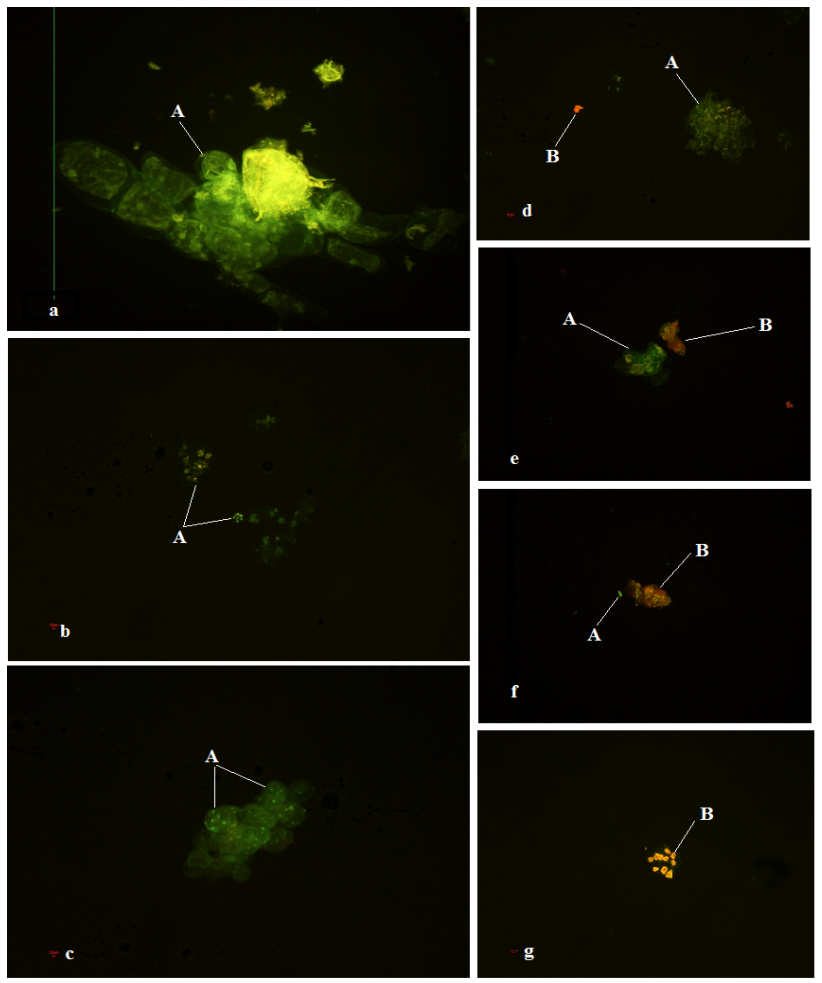

Figure 3. Cells were stained with acridine orange.

a. Cells in control treatment; $b, c, d, e, f, g$. Callus cells in additional treatments of $\mathrm{NaCl}$ at concentrations 50, 100, 150, 200, 250 and $300 \mathrm{mM}$, respectively. A. Alive cell (green); B. Dead cell (red-orange).

\subsection{Effects of $\mathrm{NaCl}$ on somatic embryogenesis of in vitro J. curcas}

The results showed that treatments with different concentrations of $\mathrm{NaCl}$ led to different somatic embryogenesis ability, rate of embryo induction and number of embryos. The highest result was recorded on treatment supplemented with $50 \mathrm{mM} \mathrm{NaCl}$. When subcultured embryogenic callus on embryo inducting medium, somatic embryos had some quickly differentiated expression on culture medium. Somatic embryos develop on four main stages: globular shape, heart shape, torpedo shape and cotyledonary shape. Treatment supplemented with $50 \mathrm{mM} \mathrm{NaCl}$ obtained the highest ratio of total number embryos $(80.00 \%)$. Higher concentrations of $\mathrm{NaCl}$ inhibited somatic embryogenesis process, that caused the ratio of inducting embryo lower than $50.00 \%(26.67 \%)$ at treatment supplemented with 150 $\mathrm{mM} \mathrm{NaCl}$. Treatment of $50 \mathrm{mM} \mathrm{NaCl}$ stimulant somatic embryogenesis derived from embryogenic callus, opposite to that, when supplementing $150 \mathrm{mM} \mathrm{NaCl}$ into culture medium, it inhibited that process (Fig 4). 

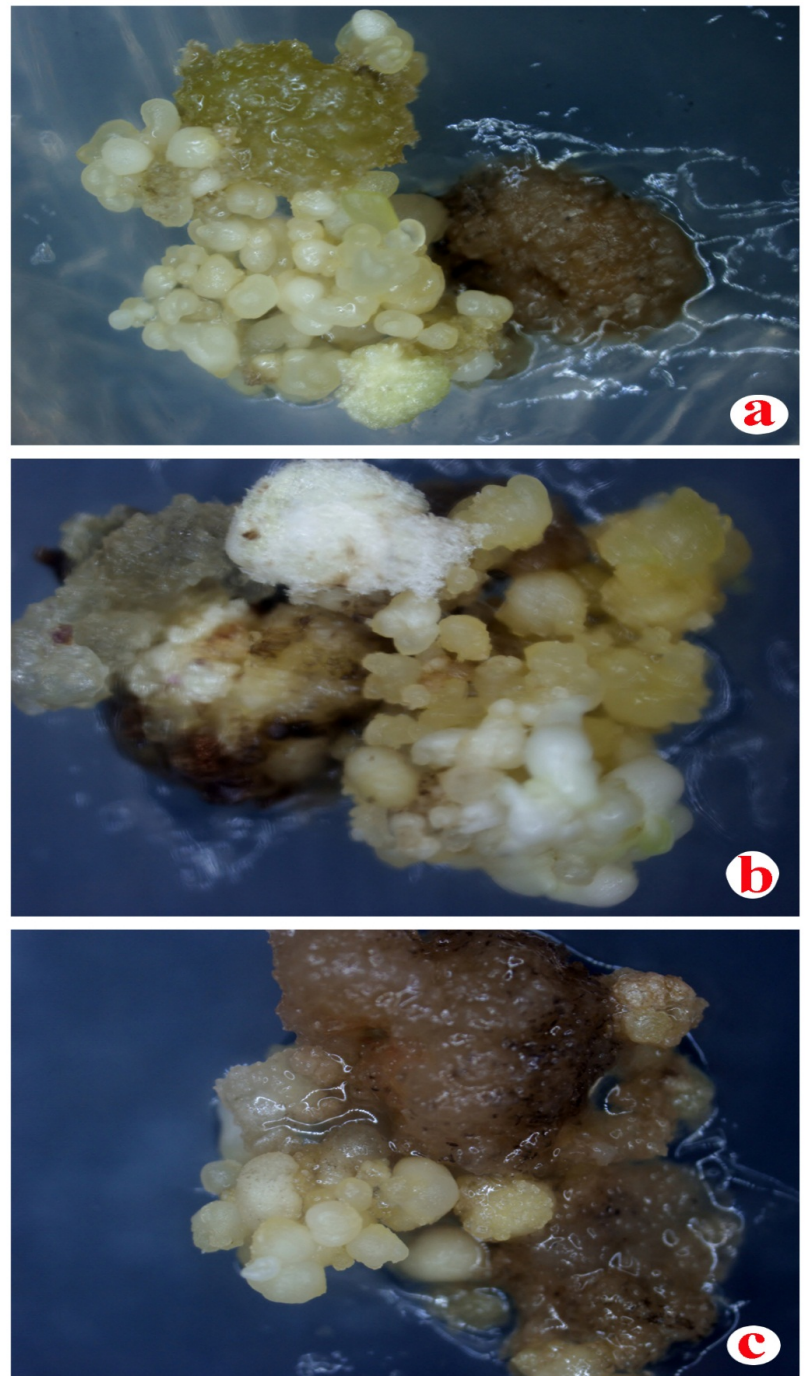

Figure 4. Effects of $\mathrm{NaCl}$ on somatic embryogenesis of callus. a. $50 \mathrm{mM}$; b. $100 \mathrm{mM}$; c. $150 \mathrm{mM}$

Table 2. Effects of $\mathrm{NaCl}$ on somatic embryogenesis derived from callus of in vitro $J$. curcas

Concentrations of $\mathrm{NaCl}$ Somatic embryogenesis

$\begin{array}{cc}(\mathbf{m M}) & \text { rate }(\mathbf{\%}) \\ \mathbf{5 0} & \mathbf{8 0 . 0 0}^{\mathbf{a}} \\ 100 & 40.00^{\mathrm{b}} \\ 150 & 26.67^{\mathrm{b}}\end{array}$

The different letters $(a, b, c, \ldots)$ in the same column show significant differences at $\alpha=0.01$ in the LSD multiple range test.

\subsection{Effects of $\mathrm{NaCl}$ on the development and} shoot formation of $\mathbf{J}$. curcas somatic embryos
At treatment that the concentration of $\mathrm{NaCl}$ was $150 \mathrm{mM}$, most of embryos exited as globular shape. Though, at treatment that the concentrations of $\mathrm{NaCl}$ were $50 \mathrm{mM}, 100$ $\mathrm{mM}$ and control treatment, embryos developed by globular stage, heart stage, torpedo stage and cotyledonary shape. Especially at $50 \mathrm{mM} \mathrm{NaCl}$, the average number of heart embryos and cotyledonary embryos were the highest ones (48 and 13.33, respectively) (Table 3, Fig 5). That confirmed when supplementing $150 \mathrm{mM} \mathrm{NaCl}$, it would exhibit the growth and germination, embryos kept their globular shape through culture progress. At the concentrations of $50 \mathrm{mM}$ and $100 \mathrm{Mm} \mathrm{NaCl}$, there are no effects on the growth of embryos. The same result was in the report of Marroquín et al. (2011) when surveying the effects of $\mathrm{NaCl}$ on embryo formation of Habanero pepper salt tolerance at $75-300 \mathrm{mM}$ of $\mathrm{NaCl}$ in culture medium.

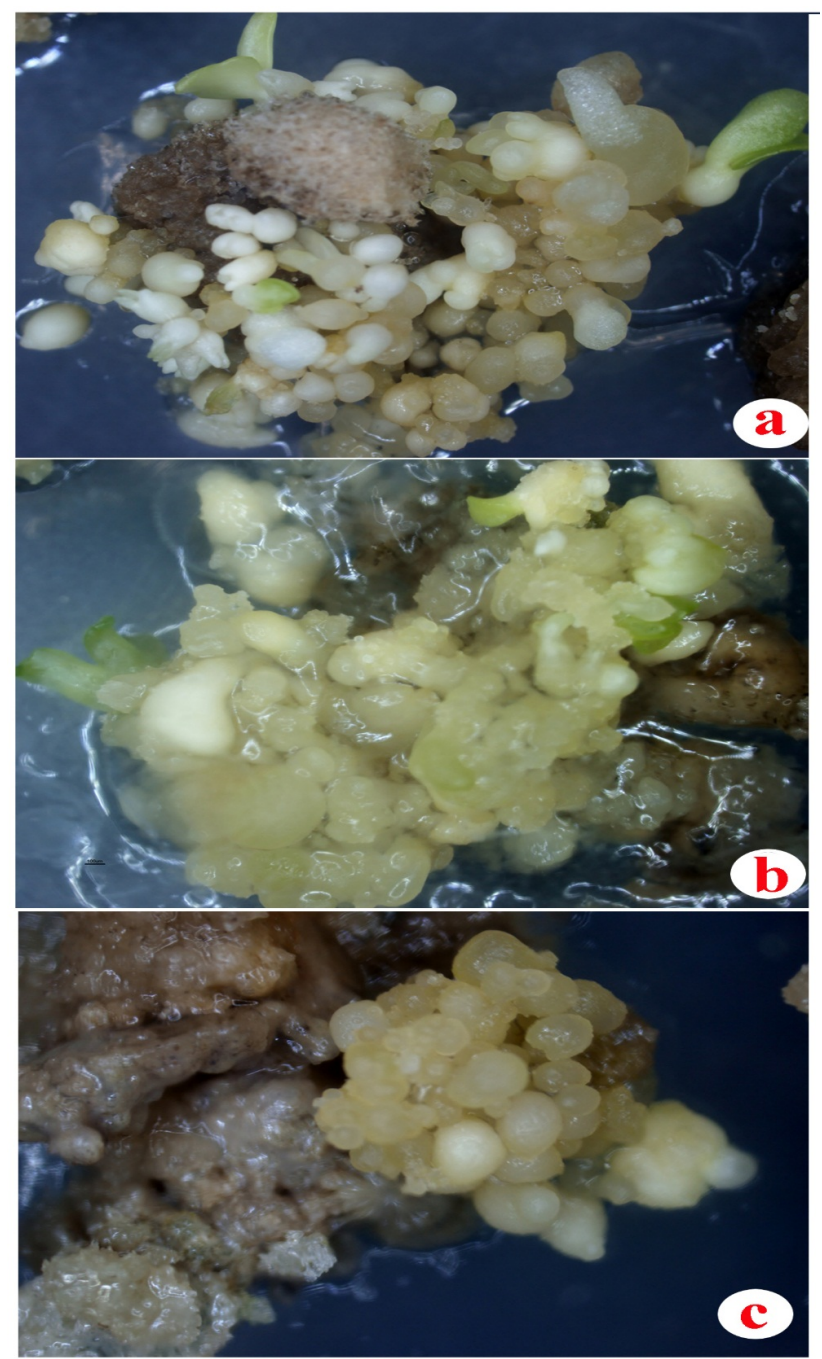

Figure 5. Effects of $\mathrm{NaCl}$ on the development of somatic embryos. a. $50 \mathrm{mM}$; b. $100 \mathrm{mM}$; $.150 \mathrm{~m}$

Table 3. Effects of $\mathrm{NaCl}$ on the development of somatic embryos of $\mathrm{J}$. curcas

\begin{tabular}{|c|c|c|c|c|c|}
\hline $\begin{array}{c}\text { Concentrations of } \\
\mathrm{NaCl} \\
(\mathbf{m M})\end{array}$ & $\begin{array}{c}\text { Total number } \\
\text { of embryos }\end{array}$ & $\begin{array}{c}\text { Number of } \\
\text { globular embryos }\end{array}$ & $\begin{array}{c}\text { Number of } \\
\text { heart embryos }\end{array}$ & $\begin{array}{l}\text { Number of } \\
\text { torpedo em- } \\
\text { bryos }\end{array}$ & $\begin{array}{l}\text { Number of } \\
\text { cotyledo- } \\
\text { nary em- } \\
\text { bryos }\end{array}$ \\
\hline 0 & $87.67^{\mathrm{a}}$ & $15.33^{b}$ & $30.67^{b}$ & $32.00^{\mathrm{a}}$ & $9.67^{\mathrm{ab}}$ \\
\hline 50 & $90.67^{a}$ & $11.00^{b}$ & $48.00^{a}$ & $18.33^{b}$ & $13.33^{\mathrm{a}}$ \\
\hline 100 & $64.00^{\mathrm{b}}$ & $9.67^{\mathrm{b}}$ & $32.67^{\mathrm{b}}$ & $15.33^{\mathrm{b}}$ & $6.33^{\mathrm{b}}$ \\
\hline 150 & $42.67^{\mathrm{c}}$ & $42.67^{\mathrm{a}}$ & $0.00^{c}$ & $0.00^{\mathrm{c}}$ & $0.00^{c}$ \\
\hline
\end{tabular}




\section{Discussion}

As the results at 3.1, there was difference between treatments with $\mathrm{NaCl}$ and control treatment. The survivability of embryogenic callus decreased while increasing $\mathrm{NaCl}$ concentration, or survival rate of embryogenic callus inversely proportional to $\mathrm{NaCl}$ concentration. In control treatment, embryogenic callus grew well and gained the highest survival rate $(100 \%)$, treatments supplemented with $\mathrm{NaCl}$ at different concentrations had lower survival rate (table 1). In this study, the salinity threshold of $J$. curcas was $50-150 \mathrm{mM}$. However, the concentrations of salinity impacts on different plants were different. Croughan et al., (1978) determined the salinity threshold of Medicago sativa cell was $1 \%(\mathrm{w} / \mathrm{v}) \mathrm{NaCl}$. While Greetha and Rao (1997) studied on Vigna radiata L., they selected salt tolerance callus line and salinity threshold was determined at $300 \mathrm{mM} \mathrm{NaCl}$. On potato plant, Ochatt et al. (1999) showed that calli which were cultured on medium containing $60 \mathrm{mM}$ to $450 \mathrm{mM} \mathrm{NaCl}$ grew well. Cotton plants has salinity threshold at $10 \mathrm{~g} / 1 \mathrm{NaCl}$, but their embryos could bear the salinity at $15 \mathrm{~g} / \mathrm{l} \mathrm{NaCl}$. This could be explained that each plant has different genotypics, different structure of cell wall and metabolism ability at each stage, which leads to the difference of absorption capacity, metabolism and abiotic stress tolerance level as well as salt tolerance pressure. Saline pressure of $\mathrm{NaCl}$ caused some changes in metabolism process of embryogenic callus, especially effecting on the osmotic ability. The osmotic ability of embryogenic callus decreased significantly when increasing the concentrations of $\mathrm{NaCl}$ in culture medium. The osmotic ability is one of the important parameter which is effected by abiotic stress, such as drought, salinity (Marroquín et al., 2011).

After determining salinity threshold of of embryogenic callus was $50-150 \mathrm{mM}$, this threshold was used to survey the embryogenesis. The result of Table 2 showed that at higher concentration of $\mathrm{NaCl}(150 \mathrm{mM})$, it inhibited somatic embryogenesis process. Treatment supplemented with $50 \mathrm{mM}$ $\mathrm{NaCl}$ obtained the highest ratio of total number embryos $(80.00 \%)$. In contrast, higher concentrations of $\mathrm{NaCl}$ inhibited somatic embryogenesis process, that caused the ratio of inducting embryo lower than $50.00 \%(26.67 \%)$ at treatment supplemented with $150 \mathrm{mM} \mathrm{NaCl}$ (Fig 4). The same thing was proved in some studies of Bekheet et al. (2006) on Allium cepa L., Habanero pepper (Marroquín et al., 2011). Saline pressure of $\mathrm{NaCl}$ strongly effects on ion exchange capacity, especially $\mathrm{K}^{+}$and $\mathrm{Na}^{+}$. The increase of $\mathrm{NaCl}$ concentration, $\mathrm{K}^{+}$content of cells decreased, while $\mathrm{Na}^{+}$concentration ascended significantly. The accumulation of $\mathrm{Na}^{+}$in issues under saline pressure seems to be main factor later than the adverse impact of salt on nutrient absorption and development (Kumar et al., 2008).

In the process of embryo development of J. curcas, at treatment that the concentration of $\mathrm{NaCl}$ was $150 \mathrm{mM}$, most of embryos exited as globular shape. Though, at treatment that the concentrations of $\mathrm{NaCl}$ were $50 \mathrm{mM}, 100 \mathrm{mM}$ and control treatment, embryos developed by globular stage, heart stage, torpedo stage and cotyledonary shape. Especially at $50 \mathrm{mM} \mathrm{NaCl}$, the average number of heart embryos and cotyledonary embryos were the highest ones (48 and 13.33, respectively) (Table 3, Fig 5). That confirmed when supplementing $150 \mathrm{mM} \mathrm{NaCl}$, it would exhibit the growth and germination, embryos kept their globular shape through culture progress. At the concentrations of $50 \mathrm{mM}$ and $100 \mathrm{Mm} \mathrm{NaCl}$, there are no effects on the growth of embryos. The same result was in the report of Marroquín et al. (2011) when surveying the effects of $\mathrm{NaCl}$ on embryo formation of Habanero pepper salt tolerance at $75-300$ $\mathrm{mM}$ of $\mathrm{NaCl}$ in culture medium. This could be explained by saline pressure factor, because of the directive effects on osmotic ability of cells, which leads to changing the metabolism. High concentrations of $\mathrm{NaCl}$ inhibit embryos growth and bipolar structure capacity of embryos, but lower concentrations of $\mathrm{NaCl}$ or non $\mathrm{NaCl}$ in medium, embryos grow normally (Mukherjee et al., 2003). Bipolar structure capacity of embryos is requisite of embryo germination process. Biosynthesis pathway that produces galactinol, fructan, trehalose, ononitol, proline and glycine betaine to regulate osmotic pressure worked on enhancing abiotic stress tolerance capacity (Qin et al., 2011).

\section{Conclusion}

Salinity threshold of of embryogenic callus was $50-150$ $\mathrm{mM}$. Treatment supplemented with $50 \mathrm{mM} \mathrm{NaCl}$ obtained the highest ratio of total number embryos $(80.00 \%)$. At 50 $\mathrm{mM} \mathrm{NaCl}$, the average number of heart embryos and cotyledonary embryos were the highest (48 and 13.33, respectively).

Acknowledgement: The authors deeply thank National Key Laboratory of Plant cell technology for supporting this study.

\section{References}

[1] Alvarez, I., Tomaro, L.M., Benavides, P.M., 2003. Changes in polyamine, proline and ethylene in sunflower calluses treated with $\mathrm{NaCl}$. Plant Cell, Tissue Org Cult. 74, 51-59.

[2] Bajaj, Y.P.S., 1987. Biotechnology in Agriculture and Forestry Vol. 3: Potato. Springer-Verlag, Berlin.

[3] Barakat, M.N., T.H. Abdel-Latif, 1996. In vitro selection of wheat callus tolerant to high levels of salt and plant regeneration. Euphytica. 91:, 127-140.

[4] Bartels, D., Sunkar, R., 2005. Drought and salt ptolerance in plants. Critical Review in Plant Sciences 24, 23-58.

[5] Bekheet, S.A., Taha, H.S., Solliman, M.E., 2006. Salt tolerance in tissue culture of onion (Allium cepa L.). Arab J. Biotech. 9(3), 467-476.

[6] Bekheet, S.A., Taha, H.S., Solliman, M.E., 2006. Salt tolerance in tissue culture of onion (Allium cepa L.) Arab J. Biotech. 9(3), 467 - 476.

[7] Do Dang Giap, Bui Van The Vinh, Nguyen Thi Kim Loan, Thai Xuan Du, Chu Thi Bich Phuong, Hoang Xuan Chien, Nguyen Phuc Huy, Tran Trong Tuan, Nguyen Dinh Lam and Duong Tan Nhut., 2012. Organogenesis and somatic embryogenesis from leaf transverse thin cell layers of Jatropha curcas L. J. Biotechol. 10(2), 281-288.

[8] Do Dang Giap, Nguyen Thi Kim Loan, Tran Trong 
Tuan, Le Thanh Tuan, Huynh Le Thien Tu, Thai Xuan Du Nguyen Dinh Lam, Duong Tan Nhut, 2013. Effects of amino acids and spermidine on somatic embryogenesis of jatropha curcas 1. J. Biology 35(3se), 136-144.

[9] Dubey, R., 1994. Protein synthesis by plants under stressful conditions. In: Mohommad, P. (ed.), Handbook of plant and crop stress. Marcel Dekker, New York, NY, 277-299.

[10] Duong, T.N., 2009. Cong nghe sinh hoc thuc vat, tap 2. Agriculture publications, HCMC.

[11] Flowers, T.J., Troke, P.F., Yeo, A.R., 1977. The mechanism of salt tolerance in halophytes. Annual Review of Plant Physiology 28, 89-121.

[12] Greeth, N., Rao, GR., 1997. Growth, proline accumulation and ion contents of $\mathrm{NaCl}$ - tolerant and sensitive callus lives of backgram (Vigna radiata $L$. Hopper). Adv Plant Sci. 10, 137 - 143.

[13] Hassan, N.S., Wilkins, D.A., 1988. In vitro selection for salt tolerant lines in Lycopersicon peruvianum. Plant Cell Rep. 7, 463-465.

[14] Huynh, T.D.S., Vo, T.B.M., 2009. Study on somatic embryogenesis of callus in Polygonum multiflorum ThunB. leaf in vitro. Science \& Technology Development 12(17), 81-85.

[15] Kumar, N., Pamidimarri, S., Kaur M., Boricha, G., Reddy M.P., 2008. Effects of $\mathrm{NaCl}$ on growth, ion accumlation, protein, proline contents and antioxidant enzymes activity in callus cultures of Jatropha curcas. Biologia 63(3), $378-382$.

[16] Lutts, S., Kinet, J.M., Bouharmont, J., 1999. Improvement of rice callus regeneration in the presence of NaCl. Plant Cell, Tiss Organ Cult. 57, 3-11.

[17] Maathuis, F.J.M., Amtmann, A., 1999. $\mathrm{K}^{+}$nutrition and $\mathrm{Na}^{+}$toxicity: the basis of cellular $\mathrm{K}^{+} / \mathrm{Na}^{+}$ratios. Annals of Botany 84, 123-133.

[18] Marroquín, D.S., Guzmán, C.A.L., Flick A.C., Bello, J.J.B., Buzzy, N.S., 2011. In vitro selection of a salt tolerant embryogenic line of Habanero pepper (Capsicum chinense Jacq.). Hort Science. 46(12), 1666 1671.

[19] Mukherjee, A., Dasgupta, M., Debata, B.K., Naskar, S.K., 2003. Enhancement of somatic embryogenesis in sweet potato: effect of growth regulators, sodium chloride, proline and maltose. Indian J. Plant Physiol. 326-331.

[20] Munns, R., 2002. Comparative physiology of salt and water stress. Plant Cell Environ. 25 (2), 239-250.

[21] Murashige, T., Skoog, F., 1962. A revised medium for rapid growth and bio assays with tobacco tissue cultures. Physiologia plantarum 15(3), 473-497.

[22] Namasivayam, P., 2007. Acquisition of embryogenic competence during somatic embryogenesis. Plant Cell Tiss. Org. 90, 1-8.

[23] Ochatt, S.J., Marconi, P.L., Radice, S., Arnozis PA., Caso O.H., 1999. In vitro recurrent selection of potato: Production and characterization of salt tolerant cell line and plants. Plant Cell Tiss Organ Cult. 55, 18.

[24] Qin, F., Shinozaki, K., Yamaguchi-Shinozaki, K., 2011. Achievements and challenges in under - standing plant abiotic stress responses and tolerance. Plant Cell Physiol. 52, 1569-1582.

[25] Quiroz-Figuera, F.R., Rojas-Herrera, R., Galaz-Avalos, R.M., Loyola-Vargas, V.M., 2006. Embryo production through somatic embriogenesis can be used to study cell differentiation in plants. Plant Cell Tiss. Org. Cult. 86: 285-301.

[26] Rai-Manoj, K., Jaiswal, V.S., Jaiswal, U., 2010. Regeneration of plantlets of guava (Psidium guajava L.) from somatic embryos developed under salt - stress condition. Acta Physiol Plant. 32, 1055-1062.

[27] Singh, N.K., Bracken, C.A., Hasegawa, P.M., Handa, A.K., Buckel, S., Hermodson, M.A., Pfankoch, F., Regnier, F.E., Bressan, R.A., 1987. Characterization of osmotin. A thaumatin - like protein associated with osmotic adjustment in plant cells. Plant Physiol. 85, 529-536.

[28] Tal, M., 1996. Somaclonal variation for salt tolerance in tomato and potato. In: Biotechnology in agriculture and forestry. (Eds.): Bajaj Y.P.S Vol. 3: Somaclonal variation in crop improvement II. Springer-Verlag, Berlin, 132-145.

[29] Zhu, J.K., 2001. Plant salt tolerance. Trends in Plant Science 6(2), 66-71. 